\title{
Suppressor Cell Regulation of Cell-mediated Immune Responses in Renal Infection
}

\author{
IN VITRO MODULATION OF SUPPRESSOR CELL ACTIVITY
}

\author{
Thomas Miller and Elaine Marshall, Department of Medicine, Auckland \\ Hospital, Auckland, New Zealand
}

A B S T R A C T Infection-induced anergy is a frequent complication of bacterial, viral, and parasitic infection. A marked suppression of the thymus-derived (T) lymphocyte response to concanavalin $A$ has been demonstrated in vitro during renal infection and the mechanisms by which suppression occurs have been investigated. In particular we have considered the possibility that suppression might result from the inhibitory effect of prostaglandins, secreted by activated macrophages with immunoregulatory potential. The experiments have shown that the T-lymphocyte effector status in experimentally-induced renal infection is determined by two suppressor cells, one infection-induced and the other naturally occurring. The inability to respond to mitogenic stimulation was reversible and restoration of immune responsiveness to splenic lymphocytes from infected animals could be achieved in two stepwise manipulations; differential centrifugation removed the infection-induced suppressor cells, and the suppressor activity of the naturally occurring suppressor cells could then be inhibited by indomethacin. Thus the two suppressor cells were distinguishable on the basis of their physical characteristics and their response to indomethacin. The dominant factor determining the immune responsiveness of splenic lymphocytes from the pyelonephritic animals was, however, the infection-induced suppressor cell. This cell has been characterized as a sedimentable cell $(30 \mathrm{~g})$ with suppressor activity demonstrable in coculture experiments. Plastic-adherent cells from the sedimentable fraction of pyelonephritic animals' splenic cells were shown to have suppressor activity that was not inhibited by indomethacin. The infection-induced and naturally occurring suppressor cells can be viewed as prototypes for the equivalent cells in man and may be useful models for studying the

Received for publication 22 October 1979 and in revised form 6 May 1.980 . role of these cells as determinants in the pathogenesis of infectious disease.

\section{INTRODUCTION}

The ability of an infectious disease to initiate an immune response in the infected host has been known for decades, but it has been recognized only recently that as well as being stimulated by infection, immune effector functions may also be depressed. As a result, the ability of the host to mount an effective immune response against an invading pathogen may be severely compromised and there are an increasing number of infectious diseases in man and experimental animals where a depressed cell-mediated immune response has been associated with an adverse clinical course $(1,2)$.

The elucidation of cellular interaction controlling the immune response to infection is one of the principal objectives in the study of the immunobiology of infectious disease. Most experiments have been directed toward characterizing subpopulations of $\mathrm{T}$ cells, but there is increasing evidence that activated macrophages are also important cellular components controlling the host's immune response to infection $(3,4)$. The direct inhibitory effect of prostaglandins secreted by activated macrophages is one likely regulatory mechanism. Goodwin et al. (5) have described a prostaglandin-producing suppressor cell in human peripheral blood that inhibits in vitro, lymphocyte activation by $\mathrm{T}$ cell mitogen. Suppressor cell activity that acts through the production of prostaglandin has been described in both experimental animals and man (6, 7). This indicates that the naturally occurring peripheral blood suppressor cells in man and splenic suppressor cells in experimental animals may be related in both function and mode of action.

Knowledge of the relationship between the naturally occurring suppressor cell in man and the suppressor cell induced during infectious disease may make a sig- 
nificant contribution to our understanding of the immunobiology of infectious disease. In the present experiments we have shown that the T-lymphocyte effector status of splenic lymphocytes in experimentally-induced renal infection is determined by two suppressor cells, one naturally occurring and the other infection induced. The two suppressor cells are distinguishable on the basis of their physical characteristics and the capacity of the prostaglandin synthetase inhibitor, indomethacin, to block the immunosuppressive activity. These cells, we believe, can be realistically viewed as prototypes of the naturally occurring suppressor cell and the infection-induced suppressor cell in man.

\section{METHODS}

Animal strain. DA $\times$ AS2 $F_{1}$ hybrid female rats weighing 200-260 $\mathrm{g}$ were used in these experiments.

Bacterial strain. The strain of Escherichia coli 075 used in these experiments was the same as that used in previous studies of experimental pyelonephritis (8).

Production of renal infection. Pyelonephritis was induced by direct inoculation of $E$. coli into the surgically exposed kidney. Details of this method have been given previously (9).

Characterization of splenic cells. Phagocytic cells were identified by their ability to ingest latex particles $(0.84 \mu \mathrm{m}$, Dow Corning Corp., Midland, Mich.) (10). Mononuclear and polymorphonuclear phagocytic cells were differentiated by direct examination of cytocentrifuged preparations. Lymphoid cells demonstrating peripheral fluorescence using fluorescein-conjugated rabbit anti-rat immunoglobulin (Wellcome Reagents Ltd., Kent, England) were identified as B cells. Surface staining was performed according to Pernis et al. (11) with minor modifications. T cells were identified using the Pta.A.1 lymphocyte-specific surface antigen $(12,13)$. The presence of the antigen Pta.A.l on the surface of the $T$ lymphocytes was determined by an indirect immunofluorescence technique involving incubation of splenic cells with Lewis anti-Fischer F344 (anti-Pta.A.1) serum followed by Huorescein-conjugated rabbit anti-rat immunoglobulin. In this procedure both $\mathrm{T}$ and $\mathrm{B}$ lymphocytes demonstrated peripheral fluorescence and the number of $T$ lymphocytes was obtained by subtracting the number of cells with surface immunoglobulin.

In vitro analysis of the mitogenic response to T-lymphocyte specific mitogens. Cultures of splenic lymphocytes were established in tissue culture tubes (Falcon Labware, Div. of Becton, Dickinson \& Co., Oxnard, Calif.; 3033). Full details of the culture procedure have been presented elsewhere (14).

Fractionation of splenic lymphocytes. Splenic lymphoid cells were prepared and the suspension was washed once in RPMI-1640 (Gibco Laboratories, Grand Island Biological Co., Grand Island, N. Y.), resuspended in $10 \mathrm{ml}$ of the same medium and then centrifuged at $30 \mathrm{~g}$ for $2 \mathrm{~min}$. Deposited cells were recovered as the "sedimentable fraction" and the lymphocytes in the supernate were labeled the "nonsedimentable fraction."

Plastic adherence. The sedimentable fraction from normal or pyelonephritic spleens was resuspended in RPMI-1640 medium containing $10 \%$ fetal calf serum. $2 \mathrm{ml}$ of medium containing varying numbers of sedimentable lymphocytes, as indicated in the text for individual experiments, were then added to plastic petri dishes (Falcon Labware, 1008) and incubated at $37^{\circ} \mathrm{C}$ for $30 \mathrm{~min}$. Nonadherent cells were removed, pooled, and cultured in test tubes with $2.5 \times 10^{6}$ normal nonsedimentable lymphocytes. The petri dishes were then washed twice with fresh medium. $3 \mathrm{ml}$ of complete medium containing $5 \times 10^{6}$ normal nonsedimentable lymphocytes were then added to each petri dish. Procedures described previously (14) were then used to determine the degree of $\left[{ }^{3} \mathrm{H}\right]$ thymidine incorporation.

\section{Preparation of agents}

Indomethacin. A stock solution of indomethacin, $500 \mathrm{mg} /$ $100 \mathrm{ml}$ in 95\% alcohol (indomethacin NF, 1475, Merck, Sharp and Dohme Ltd., New Zealand) was diluted in 95\% ethanol so that $6 \mu$ l added to cultures of splenic lymphocytes gave final concentrations of indomethacin in culture of 1 or $10 \mu \mathrm{g} / \mathrm{ml}$.

Prostaglandin $E_{1}$. A stock solution of prostaglandin $E_{1}$ (Sigma Chemical Co., St. Louis, Mo.) was prepared by dissolving $35.45 \mathrm{mg}$ of prostaglandin $\mathrm{E}_{1}$ in $1 \mathrm{ml}$ of $95 \%$ ethanol. Dilutions were made in ethanol so that $5 \mu \mathrm{l}$, when added to cultures of splenic lymphocytes, gave a range of concentrations of prostaglandin in culture between 10 and $90 \mu \mathrm{M}$.

Dibutyryl cyclic AMP. $83.1 \mathrm{mg}$ of dibutyryl cyclic AMP (Sigma Chemical Co.) was dissolved in $0.25 \mathrm{ml}$ of phosphate-buffered saline and filtered through a $0.45-\mu \mathrm{m}$ filter. $5 \mu \mathrm{l}$ of this solution and of a 1 in 10 dilution were added to lymphocyte cultures giving final concentrations of $1 \mathrm{mM}$ and $0.1 \mathrm{mM}$ dibutyryl cyclic AMP.

\section{RESULTS}

\section{Characterization of the infection-induced suppressor cell}

Morphologic evaluation of the composition of spleen cell fractions from normal and pyelonephritic animals. Renal infection led to a $43 \%$ increase in total spleen cell numbers $72 \mathrm{~h}$ after challenge, but the percentage of $\mathrm{T}$ and $\mathrm{B}$ cells in the spleen was not altered. Centrifugation at $30 \mathrm{~g}$ depleted the nonsedimentable fraction of mononuclear phagocytic cells. These cells were concentrated in the sedimentable, suppressor cell-containing fraction that consisted of 24 and $27 \%$ of the total spleen cells from normal and pyelonephritic animals, respectively (Table I).

Cells pelleted by low-speed centrifugation have suppressor activity. Splenic lymphocyte suspensions from normal and pyelonephritic animals were fractionated into a sedimentable and nonsedimentable fraction by centrifugation at $30 \mathrm{~g}$ for $2 \mathrm{~min}$. Standard cultures in triplicate were established using: (a) nonsedimentable lymphocytes from normal animals, $(b)$ sedimentable cells from normal and pyelonephritic animals sacrificed $48 \mathrm{~h}$ after challenge, and (c) coculture of the sedimentable fraction from normal and pyelonephritic animals with nonsedimentable lymphocytes from normal animals. The results (Table II) have shown that cells in the sedimentable fraction from pyelonephritic animals, when compared with sedi- 
TABLE I

Effect of $30 \mathrm{~g}$ Centrifugation on the Cellular Composition of Fractions of Splenic Cell Suspensions from Normal and Pyelonephritic Animals

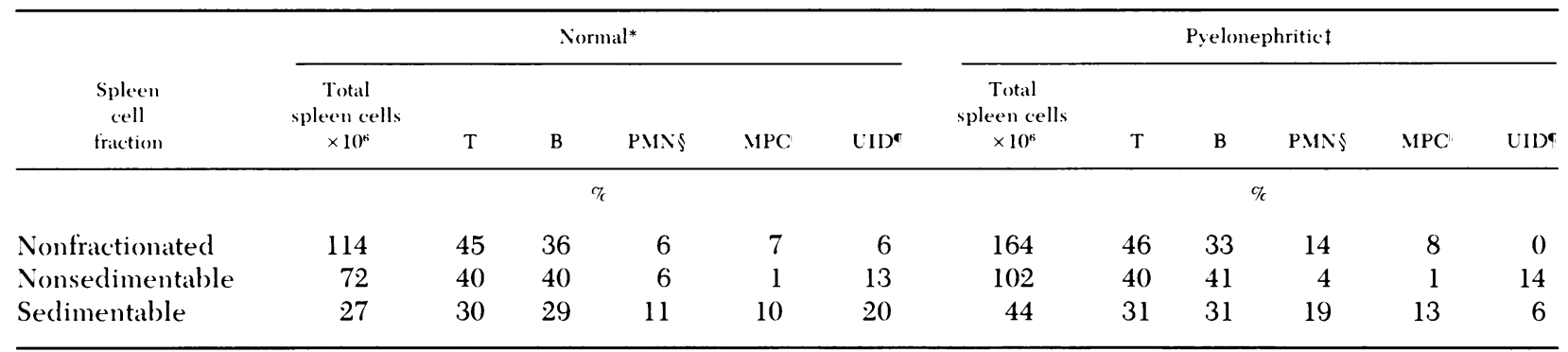

* Mean, nine normal rats.

$\$$ Mean, eight pyelonephritic rats.

\$ Polymorphonuclear leukocytes.

"Mononuclear phagocytic cells.

- Unidentified cells.

mentable cells from normal animals, can greatly suppress the Concanavalin $(\mathrm{Con})$ A response of normal splenic lymphocytes (81 vs. $8 \%$ ). Similar suppression was seen in experiments carried out $72 \mathrm{~h}$ after challenge.

Sedimentable suppressor cells display adherent characteristics. Sedimentable cells were obtained from splenic cell suspensions prepared from pyelonephritic and normal animals. Varying numbers from $1 \times 10^{6}$ to $10 \times 10^{6}$ of sedimentable cells were added to $35-\mathrm{mm}$ plastic petri dishes and allowed to adhere over a $30-\mathrm{min}$ incubation period at $37^{\circ} \mathrm{C}$. Nonadherent cells were removed and co-cultured with nonsedimentable lymphocytes from normal animals. These cells did not depress the mitogenic responsiveness of normal splenic lymphocytes; rather, enhanced responses were found when cells from the normal sedimentable but nonadherent fraction were added to the culture
(Fig. 1). Marked suppression could be demonstrated when sedimentable adherent cells from pyelonephritic animals were added to normal lymphocytes. The effect was dose dependent and could readily be differentiated, on a quantitative basis, from the suppressive activity of naturally occurring suppressor cells in the equivalent fraction of adherent cells from normal animals (Fig. 2).

Effect of indomethacin on naturally occurring and infection-induced suppressor cells. The suppression of mitogenic responses in vitro has been attributed to prostaglandin synthesis by cellular components. In these experiments we have determined whether suppression of $\mathrm{T}$ lymphocyte function, attributed to naturally occurring and infection-induced suppressor cells, could be inhibited by the prostaglandin synthetase inhibitor, indomethacin. Addition of indomethacin to unfractionated splenic lymphocytes from

TABLE II

Co-culture Demonstration of Suppressor Cell Activity in the Sedimentable Fraction of Splenic Lymphocytes from Pyelonephritic Animals

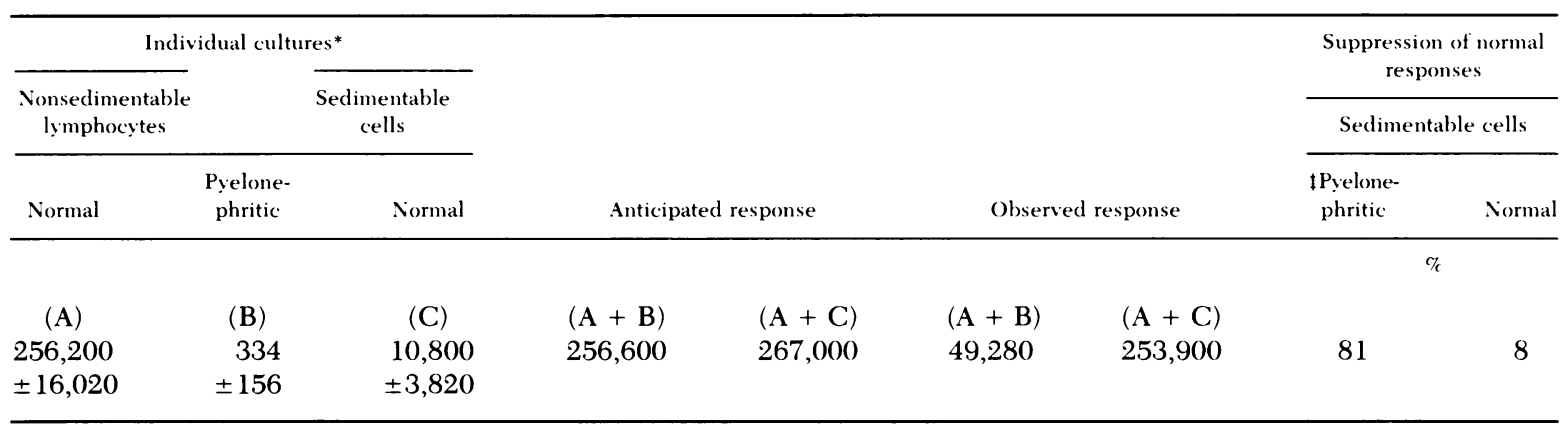

* $2.5 \times 10^{6}$ spleen cells: $\mathrm{dpm} / 10^{6}$ lymphocytes $\pm \mathrm{SEM}$.

$\$ 2.5 \times 10^{6}$ normal nonsedimentable lymphocytes $+0.6 \times 10^{6}$ sedimentable cells. Mitogenic response of lymphocytes to Con A disintegrations per minute per $10^{6}$ lymphocytes. 


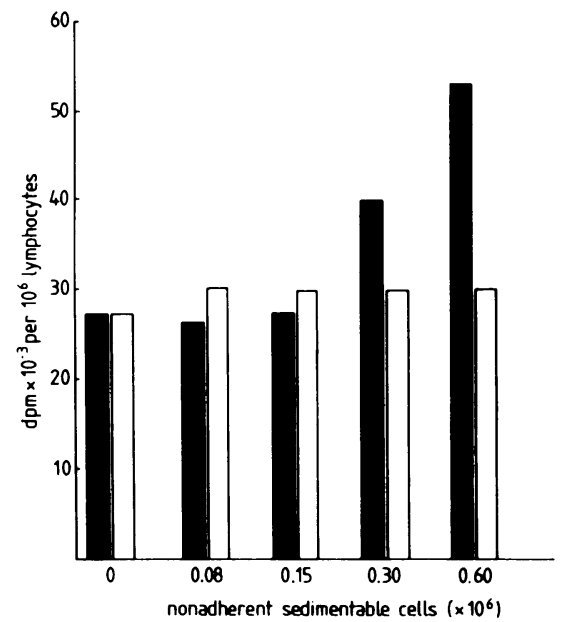

FICERE 1 Fiffect of nonadherent sedimentable cells on normal mitogenic responses. $10 \times 10^{6}$ sedimentable splenic colls from nomal (D) or prelonephritic animals ( $\square$ ) were allowed to adhere to plastic petri dishes. The nonadherent cell fraction was recovered and increasing mumbers (abscissa) were established in co-culture with $2.5 \times 10^{6}$ nomal nomsedimentable lymphocytes. Fiach hat represents the mean of triplieate analyses.

nomal rats increased the $\left[{ }^{3} \mathrm{H}\right]$ thymidine uptake by mitogen-stimulated lymphocytes from $87,900 \mathrm{dpm}$ to $321,900 \mathrm{dpm} / 10^{6}$ lymphoc.tes (Fig. 3). Indomethacin

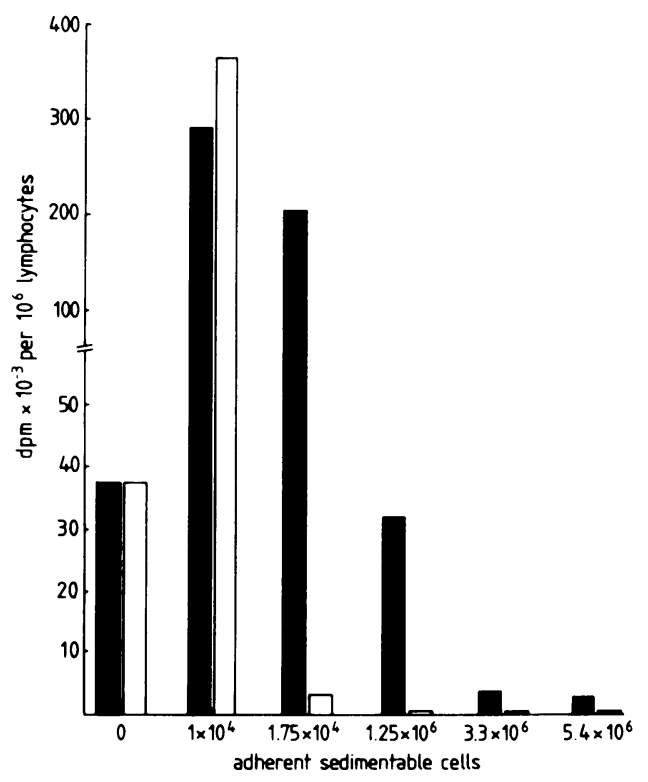

Ficicke 2 Effect of adherent sedimentable cells on nomal mitogenic responses. $1,2.5,5,7.5$, and $10 \times 10^{6}$ sedimentable splenic cells from normal (a) and pyelonephritic animals $(\square)$ were allowed to adhere to plastic petri dishes. The nonadherent cells were discarded leaving varying numbers of residual adherent cells (abscissa). $5 \times 10^{*}$ normal nonsedimentable splenic lymphocytes were then added to the petri dishes to form a co-culture. Fach bar represents the mean of (quintuplicate analyses.

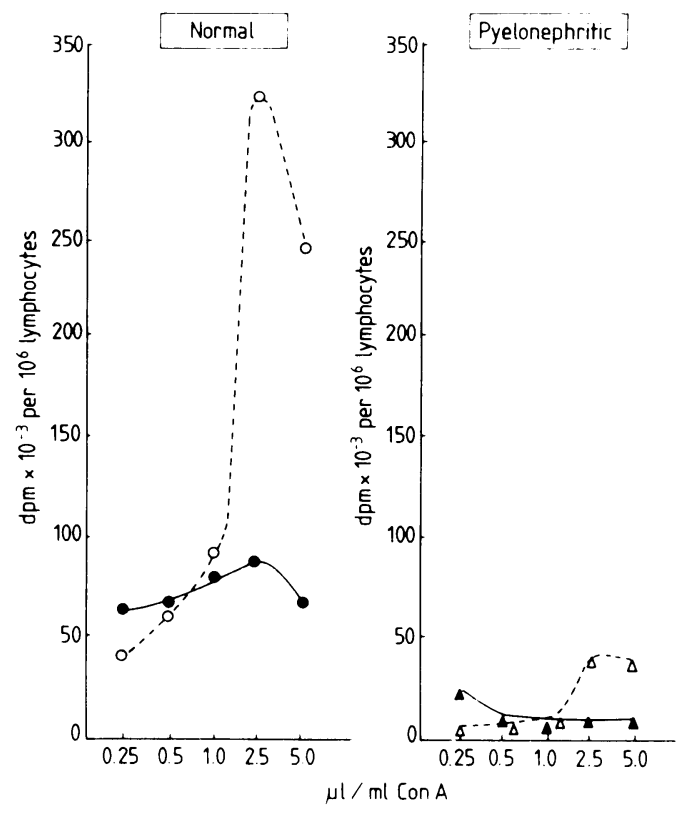

Ficire 3 Eiffect of indomethacin $(1 \mu \mathrm{g} / \mathrm{ml})$ on the mitogenic responsiveness of nonfractionated splenic lymphocestes from nomal and peelonephritic animals. Fach point is the mean of an analysis, carried out in triplicate of a pooled splenic lymphosyte population from three normal animals. Fach culture contained $2.5 \times 10^{\mathrm{k}}$ splenic lsmphosetes 0 and $\Delta$, intreated splenic lymphocytes from nomal and pyelonephritic animals. $O$ and $\triangle$, indomethacin-treated $(\mathrm{l} \mu \mathrm{g} / \mathrm{ml})$ splenic lymphocytes from nomal and prelomephritic animals.

also increased the immune responsiveness of splenic lymphocytes from pyelonephritic animals, but although the percentage increase in $\left[{ }^{3} \mathrm{H}\right]$ thymidine uptake was comparable to that seen with nomal animals (26.3 and $351 \%$, respectively), the mitogenic responsiveness of indomethacin-treated lymphocytes from the prelonephritic animals $\left(39,020 \mathrm{dpm} / 10^{6}\right.$ lymphocytes) was still only $12 \%$ of the response of the comparable population of lymphocytes from normal animals $\left(321,900 \mathrm{dpm} / 10^{6}\right.$ lymphocytes). The experiments also showed that the effect of indomethacin was related to the concentration of Con $\mathrm{A}$ but not inversely related as had been found previously (15).

Depressed cell-mediated immune response's are due to an indomethacin-insensitive suppressor cell. The results of the previous experiments suggested that the activity of the infection-induced suppressor cell was not inhibited by indomethacin. This was confirmed in the present experiment where it was found that indomethacin was unable to block the immunosuppressive activity of surface-adherent suppressor cells. The sedimentable fraction from pyelonephritic spleens was allowed to adhere to the bottom of a $35-\mathrm{mm}$ tissue culture dish for $30 \mathrm{~min}$. Nonadherent cells were then removed by repeated washings with culture medium. Duplicate suspensions of splenic lymphocytes from normal animals were established in a series of $35-\mathrm{mm}$ 
petri dishes, half of which contained the adherent cells from the spleens of pyelonephritic animals. Tritiated thymidine incorporation by Con A-stimulated lymphocytes in the absence of adherent suppressor cells $(807,200 \mathrm{dpm} /$ culture) was reduced to 112,000 $\mathrm{dpm} /$ culture when lymphocytes were cultured conjointly with adherent cells from pyelonephritic animals (Fig. 4). The addition of indomethacin $(1 \mu \mathrm{g} / \mathrm{ml})$ at the same time as the cultures were established did not inhibit the suppressor activity of the adherent cells and similar results were obtained when 10 times the concentration of indomethacin was added to the culture.

\section{Immune responsiveness can be restored to splenic lymphocytes from pyelonephritic animals in two steps}

(a) Physical removal of the infection-induced suppressor cell. Splenic lymphocytes respond to mitogenic stimulation in vitro if suppressor cells are removed. Previous studies have shown that fractionation of splenic lymphocytes from pyelonephritic animals by $30 \mathrm{~g}$ centrifugation enhanced the immune responsiveness of the nonsedimentable fraction (16). Splenic lymphocytes from normal and pyelonephritic animals were centrifuged at $30 \mathrm{~g}$ for $2 \mathrm{~min}$ and cultures of the nonsedimentable cells were established. Fractionation by centrifugation at $30 \mathrm{~g}$ resulted in a small increase in mitogenic responsiveness of the nonsedimentable cells from normal animals (76,100-98,780 $\mathrm{dpm} / 10^{6}$ cells) (Table III). In contrast there was a marked enhancement in the uptake of $\left[{ }^{3} \mathrm{H}\right]$ thymidine by the nonsedimentable cells from pyelonephritic animals $\left(4,150-53,600 \mathrm{dpm} / 10^{6}\right.$ lymphocytes).

(b) Pharmacologic inhibition of suppressor cell activity by indomethacin. The immune responsiveness

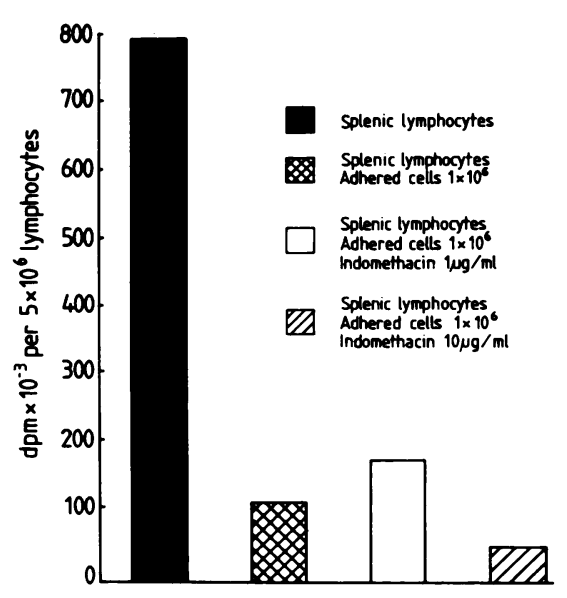

Figure 4 Effect of indomethacin ( 1 and $10 \mu \mathrm{g} / \mathrm{ml}$ ) on the suppressor activity of adherent splenic cells from pyelonephritic animals co-cultured with nonsedimentable lymphocytes from normal animals.

of the nonsedimentable splenic lymphocytes can be further enhanced by indomethacin treatment. Duplicate suspensions of nonsedimentable, pooled splenic lymphocytes from normal and pyelonephritic animals were cultured in vitro. The addition of indomethacin to half the cultures of nonsedimentable splenic lymphocytes from normal animals resulted in a marked increase in their mitogenic responsiveness. Fractionated splenic lymphocytes from pyelonephritic animals, after suppressor cells had been removed by $30 \mathrm{~g}$ centrifugation, also showed a marked increase in mitogenic responsiveness when indomethacin was added to the lymphocyte culture. Tritiated thymidine uptake increased from 81,570 to $217,200 \mathrm{dpm} / 10^{6}$ lymphocytes and exceeded the mitogenic responsiveness of a comparable splenic lymphocyte population from normal

TABLE III

Effect of Fractionation by $30 \mathrm{~g}$ Centrifugation on the Mitogenic Responses of Splenic Lymphocytes from Normal and Pyelonephritic Animals

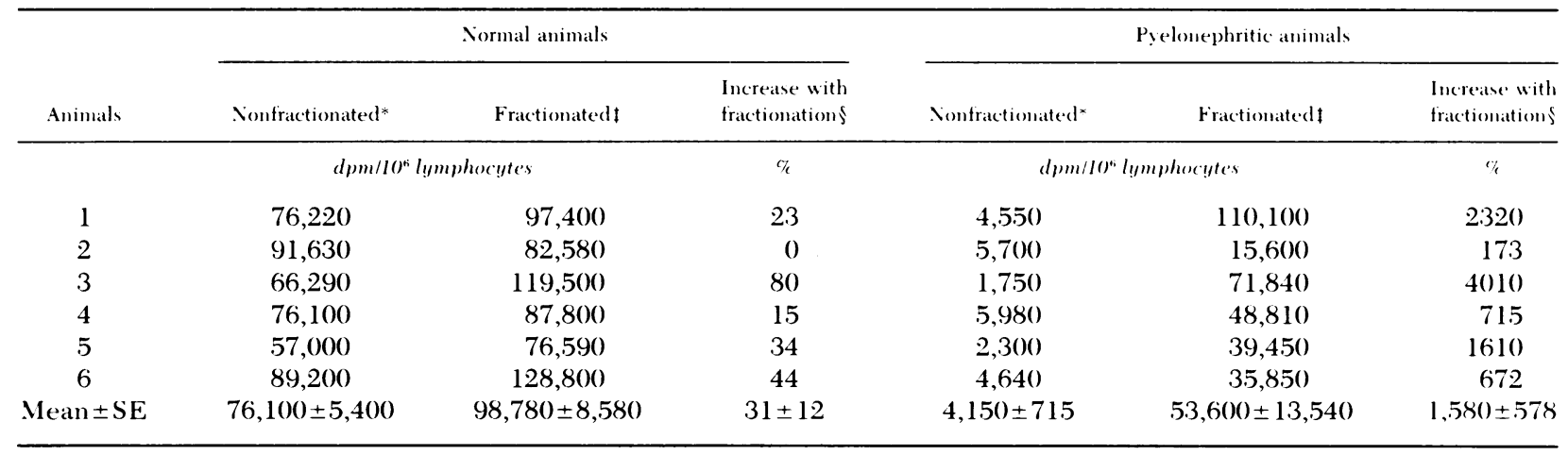

* Unmanipulated whole spleen suspension.

$\$$ Nonsedimentable fraction obtained from the whole spleen suspension following $30 \mathrm{~g}$ centrifugation.

$\$$ Increase in Con A responsiveness of lymphocytes following the removal of the sedimentable fraction by $30 \mathrm{~g}$ centrifugation. 
TABLE IV

Effect of Indomethacin on the Nonsedimentable Splenic Lymphocytes from Normal and Pyelonephritic Animals after Removal of the "30-g" Suppressor Cell

\begin{tabular}{|c|c|c|c|c|c|c|}
\hline \multirow[b]{2}{*}{$\begin{array}{l}\text { Con A per } \\
\text { milliliter } \\
\text { of culture }\end{array}$} & \multicolumn{3}{|c|}{ Normal animals } & \multicolumn{3}{|c|}{ Pyelonephritic animals } \\
\hline & $\begin{array}{l}\text { Without } \\
\text { indo- } \\
\text { methacin }\end{array}$ & $\begin{array}{l}\text { Indo- } \\
\text { methacin* }\end{array}$ & $\begin{array}{l}\text { Increase } \\
\text { with indo- } \\
\text { methacin }\end{array}$ & $\begin{array}{l}\text { Without } \\
\text { indo- } \\
\text { methacin }\end{array}$ & $\begin{array}{c}\text { Indo- } \\
\text { methacin* }\end{array}$ & $\begin{array}{c}\text { Increase } \\
\text { with indo- } \\
\text { methacin }\end{array}$ \\
\hline$\mu l$ & \multicolumn{2}{|c|}{ dpm $/ 10^{6}$ lymphocytes } & $\%$ & \multicolumn{2}{|c|}{ dpm $/ 10^{6}$ lymphocytes } & $\%$ \\
\hline 5.0 & 86,270 & 178,400 & 106 & 81,570 & 217,200 & 166 \\
\hline 2.5 & 78,120 & 108,500 & 39 & 58,270 & 89,970 & 52 \\
\hline 1.0 & 35,150 & 36,420 & 4 & 18,930 & 22,120 & 16 \\
\hline 0.15 & 22,530 & 24,370 & 8 & 15,290 & 15,190 & 0 \\
\hline 0.25 & 17,000 & 11,010 & 0 & 5,400 & 6,570 & 21 \\
\hline
\end{tabular}

${ }^{*} 1 \mu \mathrm{g} / \mathrm{ml}$ of culture.

animals (Table IV). In Table V the results of the present experiments have been summarized and show that the immune potential of splenic lymphocytes is determined by two separate suppressor cells. A naturally occurring suppressor cell, inhibited by indomethacin, was demonstrated in splenic lymphocyte suspensions from normal animals $\left(87,900-321,900 \mathrm{dpm} / 10^{6}\right.$ lymphocytes). When the infection-induced suppressor cells were first removed by $30 \mathrm{~g}$ centrifugation, however, the immune responsiveness of the nonsedimentable lymphocytes from control animals and the pyelonephritic group was comparable $(86,270$ and 81,570 $\mathrm{dpm} / 10^{6}$ lymphocytes, respectively). In the absence of the infection-induced suppressor cell, lymphocytes from pyelonephritic animals, whose immune responsiveness had been previously only partially enhanced by indomethacin $\left(39,020 \mathrm{dpm} / 10^{6}\right.$ lymphocytes compared with 321,900 for normal animals), responded to mitogenic stimulation at a level that exceeded normal splenic lymphocytes examined under the same experimental conditions $\left(217,200\right.$ vs. $178,400 \mathrm{dpm} / 10^{6}$ lymphocytes).

\section{DISCUSSION}

The experiments have demonstrated that $\mathrm{T}$ lymphocyte effector status in experimentally induced renal infection is determined by two suppressor cells; one infection-induced and the other naturally occurring. The inability to respond to mitogenic stimulation was reversible and restoration of immune responsiveness to splenic lymphocytes from infected animals was achieved in two stepwise manipulations. Differential centrifugation removed the infection-induced suppressor cells and the suppressor activity of the naturally occurring suppressor cells could then be inhibited by indomethacin. Thus the two suppressor cells were distinguishable on the basis of their physical characteristics and their response to indomethacin. The infection-induced suppressor cell was further characterized as a sedimentable cell $(30 \mathrm{~g})$ with suppressor activity demonstrable in co-culture experiments. Plastic-adherent cells from the sedimentable fraction of splenic cell suspensions from pyelonephritic animals suppressed the mitogenic responsiveness of normal

TABLE V

Effect of the "30-g" Suppressor Cell on the Indomethacin Enhanceable Mitogenic Response

\begin{tabular}{|c|c|c|c|c|c|c|c|}
\hline \multicolumn{4}{|c|}{ Normal animals } & \multicolumn{4}{|c|}{ Pyelonephritic animals } \\
\hline \multicolumn{2}{|c|}{ Nonfractionated splenocytes* } & \multicolumn{2}{|c|}{$30 \mathrm{~g}$ fractionated splenocytes } & \multicolumn{2}{|c|}{ Nonfractionated splenocytes* } & \multicolumn{2}{|c|}{$30 \mathrm{~g}$ fractionated splenocytes } \\
\hline $\begin{array}{l}\text { Without } \\
\text { indo- } \\
\text { methacin }\end{array}$ & $\begin{array}{c}\text { Indo- } \\
\text { methacin } \S\end{array}$ & $\begin{array}{l}\text { Without } \\
\text { indo- } \\
\text { methacin }\end{array}$ & $\begin{array}{c}\text { Indo- } \\
\text { methacin§ }\end{array}$ & $\begin{array}{l}\text { Without } \\
\text { indo- } \\
\text { methacin }\end{array}$ & $\begin{array}{c}\text { Indo- } \\
\text { methacin } \$\end{array}$ & $\begin{array}{l}\text { Without } \\
\text { indo- } \\
\text { methacin }\end{array}$ & $\begin{array}{c}\text { Indo- } \\
\text { methacin } \$\end{array}$ \\
\hline \multicolumn{4}{|c|}{ dpm/10 lymphocytes } & \multicolumn{4}{|c|}{$d p m / 10^{6}$ lymphocytes } \\
\hline $87,900^{\prime \prime}$ & $321,900^{\prime \prime}$ & 86,270 ㅈ & 178,400 ㅇ & $8,640^{\prime \prime}$ & $39,020^{\prime \prime}$ & 81,570 - & 217,2009 \\
\hline
\end{tabular}

* Unmanipulated whole spleen suspension.

\$ Nonsedimentable fraction obtained from the whole spleen suspension following $30 \mathrm{~g}$ centrifugation.

$\$ 1 \mu \mathrm{g} / \mathrm{ml}$ culture.

"See Fig. 3.

I See Table IV. 
lymphocytes but the immunosuppressive activity of the infection-induced suppressor cell was not inhibited by indomethacin.

Suppression of cell-mediated immunity has been demonstrated in infectious diseases both in man and experimental animals $(17,18)$. In addition to the present experiments suppressed cell-mediated immunity has also been demonstrated in tumor-bearing animals (19), experimentally induced malaria (20), schistosomiasis (21), trypanosomiasis (22), and after the injection of adjuvants (23). Thus infection-induced immune nonresponsiveness may be a much more common response of the host to infection than has been recognized previously but the nature of the biologic mechanisms that induce the immunosuppressive state is not well understood. One of the objectives of these experiments was to investigate the role of the prostaglandins as immunoregulatory molecules controlling cell-mediated immune responses to infection. Prostaglandins of the $\mathrm{E}$ series are produced by macrophages in substantial amounts after activation and can inhibit lymphocyte functions $(24,25)$. In the present experiments the addition of indomethacin, a specific prostaglandin synthetase inhibitor, to cultures of splenic lymphocytes from normal and pyelonephritic animals results in a considerable increase in the mitogenic response (351 and 263\% for normal and pyelonephritic animals, respectively). The response of pyelonephritic lymphocytes, however, was still only $12 \%$ of that of the comparable population of lymphocytes from normal animals.

Although the activity of the naturally occurring suppressor cell is inhibited by indomethacin and thus shares this and other characteristics with the naturally occurring suppressor cell found in man (5), the infection-induced suppressor cell appears to be unique. The latter cell differs from the naturally occurring suppressor cell both in physical characteristics (i.e., removable by $30 \mathrm{~g}$ centrifugation) and biologically in that its suppressor activity is not inhibited by indomethacin.

A number of investigators have described the immunosuppressive activity of surface-adherent cells, presumed to be mononuclear phagocytes, obtained from the spleens of animals challenged with a variety of stimuli (26-28). The mechanism of action of the suppressor cell has yet to be defined but a reasonable assumption is that because activated macrophages synthesize increased amounts of prostaglandin, this agent could lead to depressed cell-mediated responses. The present experiments have shown that the naturally occurring suppressor cells can depress cell-mediated immune function through prostaglandin activity. However, the mechanism by which the infection-induced suppressor cells act has yet to be defined.

One important conclusion is that although the unmanipulated splenic lymphocytes from pyelo- nephritic animals are nonresponsive in culture, full immune responsiveness can be restored. The ability of these cells to respond to mitogenic stimulation is determined by two suppressor cells. One, a naturally occurring suppressor cell, is inhibited by indomethacin but only in the absence of the infection-induced suppressor cells. A recent observation that an indomethacin-resistant splenic suppressor cell developed in mice moved from germ-free to conventional conditions (6) supports our concept of microbial infection as a factor stimulating the generation of an indomethacin-resistant suppressor cell that can be distinguished from the naturally occurring suppressor cell. It seems likely that the cell described by Mattingly et al. (6) and the infection-induced suppressor cell described in the present experiments may be derived from the same cell lineage.

These experiments have shown that the infectioninduced suppressor cell is the dominant factor determining the immune responsiveness of splenic lymphocytes from pyelonephritic animals, but unlike the naturally occurring suppressor cell, the immunosuppressive activity of the infection-induced suppressor cell is not inhibited by indomethacin. Our intention is to use both these cells as models to study the role of suppressor cells in the pathogenesis of infectious disease in man.

\section{ACKNOWLEDGMENT}

The assistance of Mrs. Jan Nelson with the morphological analyses carried out in this study is gratefully acknowledged.

The study was supported by the Medical Research Council of New Zealand.

\section{REFERENCES}

1. Rocha, H., J. W. Kirk, and C. D. Hearey, Jr. 1971. Prolonged Salmonella bacteremia in patients with Schistosoma mansoni infection. Arch. Intern. Med. 128: 254-257.

2. Booss, J., and E. F. Wheelock. 1977. Progressive inhibition of T-cell function preceding clinical signs of cytomegalovirus infection in mice. J. Infect. Dis. 135: 478481.

3. Allison, A. C. 1978. Mechanisms by which activated macrophages inhibit lymphocyte responses. Immunol. Rev. 40: 3-27.

4. Oehler, J. R., R. B. Herberman, and H. T. Holden. 1978. Modulation of immunity by macrophages. Pharmacol. Part Ther. A. 2: 551-593.

5. Goodwin, J. S., A. D. Bankhurst, and R. P. Messner. 1977 Suppression of human T-cell mitogenesis by prostaglandin. Existence of a prostaglandin-producing suppressor cell. J. Exp. Med. 146: 1719-1734.

6. Mattingly, J. A., D. D. Eardley, J. D. Kemp, and R. K. Gershon. 1979. Induction of suppressor cells in rat spleen: influence of microbial stimulation. J. Immunol. 122: 787-790.

7. Goodwin, J. S., R. P. Messner, A. D. Bankhurst, G. T. Peak, J. H. Saiki, and R. C. Williams. 1977. Prostaglandin- 
producing suppressor cells in Hodgkin's disease. N. Engl. J. Med. 297: 963-968.

8. Lehmann, J. D., J. W. Smith, T. E. Miller, J. A. Barnett and J. P. Sanford. 1968. Local immune response in experimental pyelonephritis.J.Clin. Invest. 47: 2541-2550.

9. Miller, T. E., and K. B. Robinson. 1973. Experimental pyelonephritis; a new method for inducing pyelonephritis in the rat. J. Infect. Dis. 127: 307-310.

10. WHO Technical Report. 1974. Identification, enumeration, and isolation of $\mathrm{B}$ and $\mathrm{T}$ lymphocytes from human peripheral blood. Scand. J. Immunol. 3: 521-531.

11. Pernis, B., L. Forni, and L. Amante. 1970. Immunoglobulin spots on the surface of rabbit lymphocytes. J. Exp. Med. 132: 1001-1018.

12. Howard, J. C., and D. W. Scott. 1974. The identification of sera distinguishing marrow-derived and thymusderived lymphocytes in the rat thoracic duct. Immunology. 27: 903-922.

13. Corvalan, J. R. F., and J. C. Howard. 1978. Primary in vitro antibody formation in the rat: partial characterisation and properties of an inhibitor cell present in normal spleen. Eur. J. Immunol. 8: 331-335.

14. Miller, T. E., and E. Stewart. 1979. "Filler" cells are nonimmunological cushions. Cell. Immuriol. 49: $307-316$.

15. Goodwin, J. S., R. P. Messner, and G. T. Peake. 1978. Prostaglandin suppression of mitogen-stimulated lymphocytes in vitro. Changes with mitogen dose and preincubation. J. Clin. Invest. 62: 753-760.

16. Williams, T. W., A. M. Friedlander, J. M. Lyons, and A. I. Braude. 1976. Cellular immunity in pyelonephritis: identification of suppressor cell activity of spleen cells in response to concanavalin $\mathrm{A}$ and inhibition of lymphocyte-mediated L cell cytotoxicity. I. Immunol. 116: $778-781$.

17. Mackowiak, P. A. 1978. Microbial synergism in human infections. N. Engl. J. Med. 298: 21-26.

18. Bullock, W. E., E. M. Carlson, and R. K. Gershon. 1978.
The evolution of immunosuppressive cell populations in experimental mycobacterial infection. J. Immunol. 120: 1709-1716.

19. Kirchner, H., A. V. Muchmore, T. M. Chused, H. T. Holden, and R. B. Herberman. 1975. Inhibition of proliferation of lymphoma cells and lymphocytes by suppressor cells from spleens of tumor-bearing mice. J. Immunol. 114: 206-210.

20. Freeman, R. R. 1978. T cell function during fatal and self-limiting malarial infections of mice. Cell. Immunol. 41: 373-379.

21. Coulis, P. A., R. M. Lewert, and F. W. Fitch. 1978. Splenic suppressor cells and cell-mediated cytotoxicity in murine schistosomiasis. J. Immunol. 120: 58-60.

22. Wellhausen, S. R., and J. M. Mansfield. 1979. Lymphocyte function in experimental African trypanosomiasis. II. Splenic suppressor cell activity. J. Immunol. 122: 818-824.

23. Neta, R., and S. B. Salvin. 1979. Adjuvants in the induction of suppressor cells. Infect. Immun. 23: 360-365.

24. Humes, J. L., R. J. Bonney, L. Pelus, M. E. Dahlgren, S. J. Sadowski, F. A. Kuehl, Jr., and P. Davies. 1977. Macrophages synthesise and release prostaglandins in response to inflammatory stimuli. Nature (Lond.). 269: 149-151.

25. Gordon, D., M. A. Bray, and J. Morley. 1976. Control of lymphokine secretion by prostaglandins. Nature (Lond.). 262: 401-402.

26. Bash, J. A., and B. H. Waksman. 1975. The suppressive effect of immunisation on the proliferative responses of rat $\mathrm{T}$ cells in vitro. J. Immunol. 114: 782-787.

27. Klimpel, G. R., and C. S. Henney. 1978. BCG-induced suppressor cells. I. Demonstration of a macrophagelike suppressor cell that inhibits cytotoxic $\mathrm{T}$ cell generation in vitro. J. Immunol. 120: 563-569.

28. Scott, M. T. 1974. Depression of delayed-type hypersensitivity by Corynebacterium parvum: mandatory role of the spleen. Cell. Immunol. 13: 251-263. 